Received: 10 October 2019

Revision received: 22 October 2019

Copyright $\odot 2019$ ESTP

Accepted: 24 October 2019

www.estp.com.tr

DOI 10.12738/estp.2019.4.001 • October $2019 \cdot 19(4) \cdot 1-13$

Article

\title{
Individual, Family, Peer, and School Risk Factors for Teacher Victimization*
}

\author{
Anna Sorrentino \\ Università degli Studi della Campania "Luigi Vanvitelli", \\ Caserta, Italy
}

\author{
David P. Farrington \\ Institute of Criminology, Cambridge University, \\ Cambridge, UK
}

\begin{abstract}
In recent years, bullying and cyberbullying against teachers by students have been recognized as problems affecting educators teaching in different grades. Few studies to date have addressed explanatory risk factors related to the perpetrators (students) rather than the victims (teachers) in a longitudinal design, in order to establish the possible causes of this antisocial behavior to better develop prevention and intervention programs to reduce teacher victimization. The main aim of the present study is to analyze the effect on teacher victimization of individual and interpersonal risk factors, including empathy, moral disengagement, peer and parent support, awareness of online risks, and school climate. A total of 251 Italian students (aged 11-19) participated in a longitudinal study. The results showed that, for girls, high moral disengagement, low awareness of online risks and poor school climate were risk factors for later teacher victimization. For boys, high moral disengagement and low awareness of online risks were also risk factors, in addiction to low parental support and high peer support. The findings are discussed along with possible applications for prevention and intervention.
\end{abstract}

\section{Keywords}

Teacher victimization $\bullet$ risk factors $\bullet$ ecological system theory $\bullet$ longitudinal study

* This study was part of a wider research project on student risk factors for bullying, cyberbullying and teacher victimization carried out with the support, contribution, and supervision of Anna Costanza Baldry. Sadly, Anna passed away before this article was submitted.

Correspondence to David P. Farrington, Emeritus Professor, Institute of Criminology, Cambridge University. Sidgwick Avenue, Cambridge CB3 9DA, UK. Email: dpf1@cam.ac.uk

Citation: Sorrentino, A., \& Farrington, D. P. (2019). Individual, family, peer, and school risk factors for teacher victimization. Educational Sciences: Theory and Practice, 19(4), 1 - 13. http://dx.doi.org/10.12738/estp.2019.4.001 
Violence against teachers has been studied only relatively recently (Chen \& Astor, 2009; De Wet, 2010; Dinkes, Cataldi, \& Lin-Kelly, 2007; Dworkin, Haney, \& Telschow, 1988; Dzuka \& Dalbert, 2007; Espelage et al., 2013; Gregory, Cornell, \& Fan, 2012; Kauppi \& Porhola, 2012; Moon \& McCluskey, 2016; Wilson, Douglas, \& Lyon, 2011). Most research on school-related violence has concentrated on aggression and bullying among students rather than towards teachers (see e.g., Baldry, Farrington, \& Sorrentino, 2017; Espelage et al., 2013; Farrington \& Baldry, 2010; Smith et al., 2008; Sorrentino, Baldry, Farrington, \& Blaya, 2019).

Teacher victimization by students has not been clearly studied in the literature with regard to its possible explanatory risk factors. It has some features related to bullying and cyberbullying among students (i.e., intention to harm, repetition in time), but it also has specific characteristics with regard to the imbalance of power, as students are in a "lower power position". Teacher victimization is related to both student risk factors (individual and interpersonal characteristics), and teacher risk factors, as well as to risk factors in the school context (e.g., administrative overload, low payment, overall job dissatisfaction, absence of school promoters of resilience) (see Curran, Viano, \& Fisher, 2019; Kapa \& Gimbert, 2018; Kauppi \& Porhola, 2012; Moon \& McCluskey, 2016).

A recent systematic review by Reddy, Espelage, Anderman, Kanrich, and McMahon (2018) showed that studies on teacher victimization by students have been conducted in several countries: Japan, China, a few European countries, Canada, and the USA. As far as we know, no studies have previously been carried out in Italy.

Assessing the prevalence of teacher victimization could be complex, since sampling procedures, methods and measures vary across studies (Reddy et al., 2018). In fact, in reviewing the existing literature, the prevalence rates of different types of teacher victimization by students (physical, verbal, emotional, and online) range from 4.5\% (Steffgen \& Ewen, 2007) to 94.0\% (McMahon et al., 2014). According to Longobardi, Badenes-Ribera, Fabris, Martinez, and McMahon (2018) the prevalence of self-reported teacher victimization ranges from $20 \%$ to $75 \%$.

Studies on teacher victimization can be divided into two different categories: those based on student reports, and those based on teacher accounts. Of all the 24 studies reviewed by Longobardi et al. (2018) in their systematic review and meta-analysis, only three reported results based on student reports. Few studies have investigated possible explanations of teacher victimization based on student individual and interpersonal risk factors. The majority of studies of teacher victimization focus on teacher individual, interpersonal, and school-level risk factors and are mainly based on teacher data (Reddy et al., 2018; Yang et al., 2019).

Since there has been very little investigation of victimization against teachers based on individual risk factors of the perpetrators (students), the present study aims to fill this gap in the literature by investigating teacher victimization by students in Italy. It presents the results of a short-term longitudinal study of student individual and interpersonal level risk factors by gender.

\section{Studies on Teacher Victimization by Students}

Empirical studies on teacher victimization based on student reports are scarce. As far as we know, only five studies assessed teacher victimization by involving perpetrators (students). Chen and Astor (2009) carried out a descriptive study of the prevalence of teacher victimization by surveying 14,022 students in Taiwan. The results showed that $30.1 \%$ of participants reported that they had victimized their teachers at least once during the previous year.

Based on 16,604 Israeli students, Khoury-Kassabri, Astor, and Benbenishty (2009) found that being male, having a negative perception of school policy and climate, and low SES were significant risk factors 
for student involvement in teacher victimization. Similar results were found in the study carried out by surveying 3,375 Israeli students by Khoury-Kassabri (2012). Jaureguizar, Ibabe, and Straus (2013) found, in their study of 687 Spanish students, that significant risk factors for physical violence toward teachers were student involvement in criminal behavior $(\beta=.20, p<.001)$, poor family relationships $(\beta=-.10, p<$ $.05)$, and poor classroom relationships $(\beta=.11, p<.05)$. Involvement in antisocial behavior $(\beta=.32, p<$ $.001)$ and criminal behavior $(\beta=.13, p<.05)$ significantly predicted psychological violence toward teachers.

Vanden Abeele, Van Cleemput, and Vandebosch (2017) surveyed 1,787 Flemish students about their involvement in a particular type of teacher victimization, that is taking a hurtful picture or video of the teacher. The results showed that student use of a mobile phone to take a picture or video of a teacher to ridicule him/her and student diffusion of such pictures/videos of teachers were predicted by low selfperceived popularity and peer pressure. Also, the need for popularity predicted use of the mobile phone to take a picture or video of a teacher to ridicule him/her $(\beta=.13, p<.05)$ and student diffusion of such pictures/videos of teachers $(\beta=.20, p<.05)$.

The only cross-cultural study of teacher victimization based on students' reports was carried out by Benbenishty, Astor, López, Bilbao, and Ascorra (2018) by surveying 24,243 Israeli and Chilean students. The results showed that males, in both cultural groups, were more involved than females in teacher victimization. With regard to student age, different patterns emerged. Chilean older students reported low levels of involvement in victimizing teachers than younger students, while on the contrary, older Israeli students reported being more involved in teacher victimization than their younger peers.

Few studies have been carried out by collecting teacher victimization data from students, and little is known about risk and protective factors for teacher victimization. The key question is: which factors at the individual, interpersonal, community, and social level play a role in predicting and explaining teacher victimization by students? Even less is known about risk and protective factors for violence against teachers based on a longitudinal design, as most studies conducted in this field are cross-sectional and lack a strong theoretical explanatory model.

\section{The Social Ecological Framework}

In the present study, we tried to fill this gap in the literature by investigating the possible explanatory role of student individual and social risk factors that might contribute to victimization against teachers in the context of the Ecological System Theory (Bronfenbrenner, 1986). This framework had been widely used to investigate risk and protective factors for school violence and bullying (Espelage et al., 2013; Martinez et al., 2016; Moon \& McCluskey, 2016; SooHyun \& Wilcox, 2018), and cyberbullying among peers (Baldry, Farrington, \& Sorrentino, 2015; Cross et al., 2015), and to increase knowledge about individual and school-level predictors of teacher victimization (Yang et al., 2019).

However, the socio-ecological framework could also be of use to investigate teacher victimization by studying risk and protective risk factors related to the perpetrator (student), not only to the victim (teacher). The ecological approach (Bronfenbrenner, 1986) addresses a broader range of explanatory factors for teacher victimization. This is a useful approach to investigate why some students would victimize their teachers and what characteristics lead them to act aggressively (Hong \& Espelage, 2012; Reddy et al., 2018).

We include in this study student individual, interpersonal, and contextual risk factors that have been significantly associated with involvement in aggressive behaviors at school (Baldry et al., 2015; Espelange et al., 2013). In particular, we include low empathy (Zych, Baldry, Farrington, \& Llorent, 2019), high moral disengagement (Runions \& Bak, 2015), low peer support (Vanden Abeele et al., 2017), low parental support (Jaureguizar et al., 2013; Kapa, Luke, Moulthrop, \& Gimbert, 2018), a low level of awareness of online risks, and poor school climate (Huang, Eddy, \& Camp, 2017; SooHyun \& Wilcox, 2018). 
Furthermore, as individual risk factors might play a different role in boys and girls (Cappadocia, Craig, \& Pepler, 2013; Hinduja \& Patchin, 2008; Holt, Fitzgerald, Bossler, Chee, \& Ng, 2016; Sticca, Ruggieri, Alsaker, \& Perren, 2013), gender was not used as a predictive risk factor, but we investigated the role of risk factors separately for boys and girls. Gender differences could be key aspects in understanding victimization against teachers.

\section{Methods}

\section{Participants}

A total of 251 Italian students (53.7\% males), aged between 11 and 19 years $(M=13.9, S D=2.3)$, took part in the longitudinal study. One third (33.0\%) spent on average from 2 to 4 hours a day on the Internet and $72.8 \%$ reported having more than one profile on social network sites. Participants were recruited from four different public schools: three middle schools (10-14-year-old students) (58.6\%) and one high school (14-18-year-old students) (41.4\%) located in Naples and the surrounding provinces (Southern Italy). The schools were representative of the types of schools for students aged 10-18 in Italy (middle and high schools) and represented a variety of socio-economic statuses, although schools were not randomly selected. In this study, we reported data from the first wave of data and a follow-up of six months.

\section{Instruments}

The Tabby Improved checklist (Baldry, Blaya, \& Farrington, 2018) (available at www.tabby.eu), developed by analyzing the results of a review of the international literature on risk factors for youngsters' involvement in cyberbullying and cybervictimization, was used to measure the dimensions under investigation and to assess the relationship between socio-demographic variables, individual risk factors and subsequent teacher victimization. The complete Tabby Improved checklist consists of 12 scales measuring different dimensions. However, for the current study and according to the theoretical model under investigation, only the following dimensions were analyzed.

Students' aggressive behaviors against teachers were measured using four "yes" or "no" questions, with total scores ranging from 0 to 4 (e.g., "Have you teased your teachers online?"). Students with a total score $>1$ were classified as involved in some form of aggressive behavior against teachers $(\alpha=.66)$.

Empathy was measured using the Basic Empathy Scale (Albiero, Matricardi, Speltri, \& Toso, 2009; Jolliffe \& Farrington, 2006), consisting of 20 items each measured on a 5-point Likert scale ranging from 1 $=$ "Strongly disagree" to $5=$ "Strongly agree" $(\alpha=.85)$.

Moral Disengagement was measured using the Bandura, Barbaranelli, Caprara, and Pastorelli (1996) scale, adapted and validated in Italian by Caprara, Bandura, Barbaranelli, and Vicino (1996), consisting of 32 items each measured on a 5-point Likert scale ranging from 1 = "Strongly disagree" to 5 = "Strongly agree" $(\alpha=.93)$.

To measure students' awareness of online risks, the Increasing Self-Awareness of Cyberbullying (ISAC) scale was developed. The scale consists of 6 items each measured on a 5-point Likert scale ranging from 1 = "Strongly agree" to 5 = "Strongly disagree" (e.g., "Everybody could see my notice board on my social network profile(s)" and "To share online someone's photos or other materials. It's just a way to mock them"), $(\alpha=.82)$.

To measure students' parental support (e.g., "My family really tries to help me" and "I can talk about my problems with my family") and peer support (e.g., "My friends really try to help me" and "I have friends with whom I can share my joys and sorrows"), two sub-scales of the Multidimensional Scale of Perceived Social Support Assessment were used (Zimet, Dahlem, Zimet, \& Farley, 1988; Zimet, Powell, 
Farley, Werkman, \& Berkoff, 1990). Each subscale consists of 4 items each measured on a 7-point Likert scale ranging from $1=$ "Strongly agree" to $7=$ Strongly disagree" (respectively $\alpha=.92$ for parental support, $\alpha=.93$ for peer support).

School climate was measured with a new eight item scale (e.g., "If I have some problems I can count on teachers help and support" and "Most of the students support and participate with interest in all school's activities"), each measured from 1= "Strongly Disagree" to $5=$ "Strongly Agree" $(\alpha=.85)$.

\section{Procedure}

Schools participating in the study were contacted by the first author, to implement a short-term longitudinal study on risk factors for student involvement in cyberbullying and teacher victimization. Before data collection, the approval of the Department of Psychology Ethical committee of the "Università degli Studi della Campania "Luigi Vanvitelli", and of the custodial adults and students, were obtained. The same students completed an online questionnaire twice: in November (T1) and in the following May (T2). On the first day, students were approached in their schools and were asked to sit in front of a PC in the computer room of the school, connected to an online website where the anonymous questionnaire could be completed. Students were told that the questionnaire was on their use of communication technologies and their behaviors online, on their attitudes towards the use of social networks and messaging online, and about their relationships with teacher.

At each data collection wave, the reference period was the previous six months. Students filled in the questionnaire in the presence of the first author and of a teacher from that class who monitored the procedure but stayed away from the computers that students were using in order to guarantee them some degree of privacy. Students were told that no-one, but the researchers could have access to their answers that, once provided, went automatically into a database for subsequent analyses performed at an aggregate level, and that they could withdraw the study and be involved in some other activities. No student withdrew from the study, and all participants completed the survey. Students were also instructed about generating an ID code, to allow the researchers to match the two data collection waves and reduce doubtful cases and errors. After completing the questionnaire, all students returned to their class for a short debriefing and to have any questions answered.

\section{Data Analysis}

Data analyses were carried out using the SPSS statistical package (version 21.0, IBM Milano, Milan, Italy). First, we looked at possible gender differences in student involvement in teacher victimization at baseline (T1). Then we investigated baseline (T1) risk factors for teacher victimization at baseline (T1) and after 6 months (T2). For both analyses, we used odds ratios (OR) to measure the strength of relationships, because (unlike chi-squared, for example) they are not influenced by sample size. All risk factors were dichotomized at the median for these analyses. In order to investigate independently predictive risk factors for student aggressive behavior against teachers (after 6 months, at T2), binary logistic regression analyses were performed separately for boys and girls.

\section{Results}

\section{Gender Differences in Teacher Victimization}

Overall, $23.1 \%$ of participants reported they had victimized their teachers at least once in the previous six months; $9.6 \%$ and $5.6 \%$ of students, respectively, reported that they had insulted their teachers 
at school and online; $17.9 \%$ of participants admitted that they had teased their teachers online, while 3.2\% reported that they had physically attacked their teachers.

Odds Ratios (OR) in Table 1 show gender differences in teacher victimization; $7.4 \%$ of boys versus $3.4 \%$ of girls admitted insulting teachers online in the previous six months; $20.0 \%$ of boys versus $15.5 \%$ of girls reported teasing their teachers online; $5.2 \%$ of boys versus $0.9 \%$ of girls reported that they had physically attacked their teacher. This last gender difference was large but not significant. Overall, 24.4\% of boys and $21.6 \%$ of girls had victimized teachers (not significantly different).

Table 1. Gender differences in risk factors and teacher victimization at T1 $(N=251)$

\begin{tabular}{|c|c|c|c|}
\hline & $\operatorname{Male}(N=135)$ & OR (C.I.) & Female $(N=116)$ \\
\hline $\begin{array}{l}\text { Have you insulted your teachers } \\
\text { at school? }\end{array}$ & 9.6 & $1.01(0.39-2.60)$ & 9.5 \\
\hline $\begin{array}{l}\text { Have you insulted your teachers } \\
\text { online? }\end{array}$ & 7.4 & $2.27^{\dagger}(0.61-8.46)$ & 3.4 \\
\hline $\begin{array}{l}\text { Have you teased your teachers } \\
\text { online? }\end{array}$ & 20.0 & $1.36^{\dagger}(0.71-2.83)$ & 15.5 \\
\hline $\begin{array}{l}\text { Have you physically attacked } \\
\text { your teachers? }\end{array}$ & 5.2 & $6.04(0.63-57.61)$ & 0.9 \\
\hline $\begin{array}{l}\text { Students' aggressive behavior } \\
\text { against teachers }\end{array}$ & 24.4 & $1.17(0.65-2.13)$ & 21.6 \\
\hline & & $t$ & \\
\hline Low empathy & $M=29.29(S D=9.89)^{\mathrm{a}}$ & $-.5 .51 * * *$ & $M=22.31(S D=10.11)$ \\
\hline 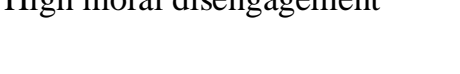 & $22.27)^{\circ}$ & $-3.15 * *$ & $M=06.43(3 D=19.10)$ \\
\hline Low awareness of online risks & $M=8.16(S D=6.04)^{\mathrm{c}}$ & $-.3 .94 * * *$ & $M=5.46(S D=4.80)$ \\
\hline Low parental support & $M=8.34(S D=5.37)$ & -0.61 & $M=7.96(S D=5.66)$ \\
\hline Low peer support & $M=10.67(S D=5.94)$ & -0.54 & $M=10.21(S D=6.00)$ \\
\hline Poor school climate & $M=13.23(S D=6.30)$ & -0.05 & $M=13.19(S D=7.45)$ \\
\hline
\end{tabular}

Note. ${ }^{\dagger} p<.10 ; * p<.05 ; * * p<.01 ; * * * p<.001$.

There were gender differences in mean scores of empathy, moral disengagement, and awareness about risky online behaviors, while no significant gender differences were found with regard to support by parents and peers and school climate. In particular, boys were significantly less empathic, more morally disengaged and less aware of online risks than girls.

\section{Student Risk Factors for Teacher Victimization}

Student individual, interpersonal, and contextual risk factors, measured at baseline (T1), were analyzed in order to study the existence of possible gender differences in risk factors for teacher victimization at baseline (T1) and after 6 months (T2). Table 2 shows that low empathy was negatively related to teacher victimization at $\mathrm{T} 1$ for boys, but positively related for girls. However, neither relationship was statistically significant. High moral disengagement was significantly related to teacher victimization 
for boys, but not for girls. Low awareness of online risks, low parental support, and poor school climate were significantly related to teacher victimization for both boys and girls. Low peer support was not significantly related to teacher victimization for either boys or girls.

Table 2. Student risk factors at $T 1$ versus teacher victimization at baseline (T1)

\begin{tabular}{|c|c|c|c|c|}
\hline \multirow[b]{4}{*}{ Low empathy } & \multicolumn{4}{|c|}{ Students' aggressive behavior against teachers at T1 } \\
\hline & \multicolumn{2}{|c|}{ Male } & \multicolumn{2}{|c|}{ Female } \\
\hline & $\%$ of Involved & $\%$ of Not involved & $\%$ of Involved & $\%$ of Not involved \\
\hline & 54.5 & 59.8 & 40.0 & 30.8 \\
\hline OR (C.I.) & \multicolumn{2}{|c|}{$0.81(0.37-1.78)$} & \multicolumn{2}{|c|}{$1.50(0.60-3.75)$} \\
\hline High moral disengagement & 69.7 & 49.0 & 48.0 & 37.4 \\
\hline OR (C.I.) & \multicolumn{2}{|c|}{$2.39 *(1.04-5.53)$} & \multicolumn{2}{|c|}{$1.55(0.63-3.78)$} \\
\hline Low awareness of online risks & 87.9 & 44.1 & 60.0 & 22.0 \\
\hline OR (C.I.) & \multicolumn{2}{|c|}{$9.18 * * *(3.01-28.04)$} & \multicolumn{2}{|c|}{$5.33 * * *(2.08-13.65)$} \\
\hline Low parental support & 57.6 & 24.5 & 64.0 & 20.9 \\
\hline OR (C.I.) & \multicolumn{2}{|c|}{$4.18 * * *(1.83-9.54)$} & \multicolumn{2}{|c|}{$6.74 * * *(2.58-17.60)$} \\
\hline Low peer support & 45.5 & 45.1 & 48.0 & 38.5 \\
\hline OR (C.I.) & \multicolumn{2}{|c|}{$1.01(0.46-2.23)$} & \multicolumn{2}{|c|}{$1.48(0.61-3.60)$} \\
\hline Poor school climate & 72.7 & 39.2 & 64.0 & 40.7 \\
\hline OR (C.I.) & \multicolumn{2}{|c|}{$4.13 * * *(1.74-9.80)$} & \multicolumn{2}{|c|}{$2.60 *(1.04-6.50)$} \\
\hline
\end{tabular}

Note. $* p<.05 ; * * p<.01 ; * * * p<.001$.

Timing to the prediction of teacher victimization at T2 six months later, low empathy was not significantly predictive for either boys or girls (see Table 3 ).

Table 3. Student risk factors at T1 versus teacher victimization after six months (T2)

\begin{tabular}{|c|c|c|c|c|}
\hline & \multicolumn{4}{|c|}{ Students' aggressive behavior against teachers at $T 2$} \\
\hline & \multicolumn{2}{|c|}{ Male } & \multicolumn{2}{|c|}{ Female } \\
\hline & $\%$ of Involved & $\%$ of Not involved & $\%$ of Involved & $\%$ of Not involved \\
\hline Low empathy & 56.7 & 59.0 & 47.6 & 29.5 \\
\hline OR (C.I.) & \multicolumn{2}{|c|}{$0.91(0.40-2.06)$} & \multicolumn{2}{|c|}{$2.18(0.83-5.70)$} \\
\hline High moral disengagement & 76.7 & 47.6 & 76.2 & 31.6 \\
\hline OR (C.I.) & \multicolumn{2}{|c|}{$3.61 * *(1.43-9.15)$} & \multicolumn{2}{|c|}{$6.93 * * *(2.32-20.69)$} \\
\hline Low awareness of online risks & 80.0 & 47.6 & 57.1 & 24.2 \\
\hline OR (C.I.) & \multicolumn{2}{|c|}{$4.40 * *(1.66-11.64)$} & \multicolumn{2}{|c|}{$4.17 * *(1.56-11.16)$} \\
\hline Low parental support & 46.7 & 28.6 & 57.1 & 24.2 \\
\hline OR (C.I.) & \multicolumn{2}{|c|}{$2.19^{\dagger}(.95-5.03)$} & \multicolumn{2}{|c|}{$4.17 * *(1.56-11.16)$} \\
\hline Low peer support & 33.3 & 48.6 & 42.9 & 40.0 \\
\hline OR (C.I.) & \multicolumn{2}{|c|}{$0.53(0.23-1.24)$} & \multicolumn{2}{|c|}{$1.13(0.43-2.93)$} \\
\hline Poor school climate & 53.3 & 45.7 & 76.2 & 38.9 \\
\hline OR (C.I.) & \multicolumn{2}{|c|}{$1.36(0.60-3.06)$} & \multicolumn{2}{|c|}{$5.02 * *(1.69-14.85)$} \\
\hline
\end{tabular}

Low peer support was also not significantly predictive, but it was negatively related to teacher victimization for boys $(O R=0.53)$. This suggests that high peer support may encourage teacher victimization by boys. High moral disengagement and low awareness of online risks significantly predicted teacher victimization for boys and girls. Low parental support was significantly predictive for girls and almost significantly predictive for boys. Poor school climate was significantly predictive for girls but not for boys. 


\section{Teacher Victimization at Baseline (T1)}

Two logistic regressions were carried out, to establish independent risk factors for teacher victimization at baseline, separately for boys and girls. The results in Table 4 show that low awareness of online risks and low support by parents were significant risk factors for both boy and girl involvement in teacher victimization at baseline.

Table 4. Logistic regression for risk factors at T1 versus teacher victimization at $T 1$

\begin{tabular}{|c|c|c|c|c|c|c|c|c|c|c|}
\hline & Male & $B(S E)$ & $O R$ & 95 C.I. & for $O R$ & Female & $B(S E)$ & $O R$ & 95 C.1 & for $O R$ \\
\hline & & & & Lower & Upper & & & & Lower & Upper \\
\hline & & & & Bound & Bound & & & & Bounc & Bound \\
\hline Low empathy & & $0.72(0.51)$ & 2.05 & 0.76 & 5.51 & & $0.40(0.61)$ & 1.50 & 0.46 & 4.93 \\
\hline $\begin{array}{l}\text { High moral } \\
\text { disengagement }\end{array}$ & & $0.35(0.51)$ & 1.41 & 0.52 & 3.82 & & $-0.03(0.56)$ & 0.97 & 0.32 & 2.93 \\
\hline $\begin{array}{l}\text { Low awareness of } \\
\text { online risks }\end{array}$ & & $2.01(0.61)$ & $7.45 * * *$ & 2.24 & 24.85 & & $1.40(0.53)$ & $4.06^{* *}$ & 1.43 & 11.50 \\
\hline Low parental support & & $1.42(0.52)$ & $4.12 * *$ & 1.49 & 11.39 & & $1.69(0.58)$ & $5.40 * *$ & 1.74 & 16.74 \\
\hline Low peer support & & $-0.42(0.51)$ & 0.66 & 0.24 & 1.78 & & $-0.12(0.55)$ & 0.89 & 0.31 & 2.60 \\
\hline Poor school climate & & $0.86(0.50)$ & $2.37 f$ & 0.89 & 6.33 & & $0.56(0.53)$ & 1.76 & 0.62 & 5.00 \\
\hline & $\begin{array}{l}R^{2}= \\
X^{2}\end{array}$ & $\begin{array}{l}\text { (Cox and } \\
37.43 * * *\end{array}$ & hell). & $(\mathrm{Na}$ & rke). & $\begin{array}{l}R^{2}= \\
X^{2}{ }_{(6}\end{array}$ & $\begin{aligned} & 4(\mathrm{Cox} \text { and } \mathrm{S} \\
= & 37.43^{* * *}\end{aligned}$ & ell). . & $(\mathrm{Na}$ & (erke). \\
\hline
\end{tabular}

Note. ${ }^{\dagger} p<.10 ; * p<.05 ; * * p<.01 ; * * * p<.001$.

\section{Teacher Victimization After Six Months (T2)}

Two logistic regressions were carried out to establish risk factors that independently predicted teacher victimization, separately for boys and girls. Table 5 shows that high moral disengagement was significantly predictive for both boys and girls.

Table 5. Logistic regression for risk factors at $T 1$ versus teacher victimization at $T 2$

\begin{tabular}{|c|c|c|c|c|c|c|c|c|c|c|}
\hline & Male & $B(S E)$ & $O R$ & 95 C.I. & or $O R$ & Female & $B(S E)$ & OR & 95 C.I & for $O R$ \\
\hline & & & & Lower & Upper & & & & Lower & Upper \\
\hline & & & & Bound & Bound & & & & Bounc & Bound \\
\hline Low empathy & & $0.37(0.49)$ & 1.45 & 0.56 & 3.76 & & $0.41(0.67)$ & 1.50 & 0.41 & 5.57 \\
\hline $\begin{array}{l}\text { High moral } \\
\text { disengagement }\end{array}$ & & $1.09(0.52)$ & $2.99 *$ & 1.08 & 8.33 & & $1.88(0.65)$ & $6.53 * *$ & ${ }^{*} 1.83$ & 23.26 \\
\hline $\begin{array}{l}\text { Low awareness of } \\
\text { online risks }\end{array}$ & & $1.46(0.54)$ & $4.32 * *$ & * 1.49 & 12.56 & & $1.09(0.60)$ & $3.00^{\dagger}$ & 0.93 & 9.64 \\
\hline $\begin{array}{l}\text { Low parental } \\
\text { support }\end{array}$ & & $0.99(0.53)$ & $2.71^{\dagger}$ & 0.96 & 7.59 & & $0.85(0.64)$ & 2.34 & 0.67 & 8.22 \\
\hline Low peer support & & $-1.10(0.51)$ & $0.33^{*}$ & 0.12 & 0.90 & & $-0.24(0.59)$ & 0.79 & 0.25 & 2.51 \\
\hline Poor school climate & & $-0.45(0.50)$ & 0.64 & 0.24 & 1.69 & & $1.48(0.64)$ & $4.38 * *$ & ${ }^{*} 1.26$ & 15.20 \\
\hline & $\begin{array}{l}R^{2}=.16 \\
X_{(6)}^{2}=\end{array}$ & $\begin{array}{l}16(\mathrm{Cox} \text { and } \mathrm{S} \\
=23.28^{* * *} \\
\end{array}$ & nell). .2 & & kerke). & $\begin{array}{l}R^{2}=.22 \\
X^{2}{ }_{(6)}=\end{array}$ & $\begin{array}{l}\text { Cox and } \mathrm{Sr} \\
9.30^{* * *}\end{array}$ & 1). . 3 & & erke). \\
\hline
\end{tabular}

Low awareness of online risks was significantly predictive for boys and almost significantly predictive for girls. Poor school climate was significantly predictive for girls but not for boys. Low parental support was almost significantly predictive for boys. Low peer support was a significant negative predictor for boys, showing that high peer support significantly predicted teacher victimization. 


\section{Discussion}

Aggression against teachers by students is not a new problem and has not received its deserved scientific and research attention, resulting in an underestimation of its effects on teachers' school performance and their wellbeing (Espelage \& Swearer, 2004; Reddy et al., 2018). The majority of the existing studies on the prevalence and nature of victimization against teachers are based on teacher reports, and none of them examined teacher victimization in Italy.

In this study, we wanted to look at teacher victimization by investigating student individual, interpersonal and contextual risk factors. We did this to understand what possible risk factors play a role, adopting a risk factor model based on the ecological system theory (Bronfenbrenner, 1986). In particular, we investigated, separately for boys and girls, the relationship of individual, interpersonal and contextual risk factors to subsequent involvement in victimization against teachers. To the best of our knowledge, this is one of the first studies looking at student risk factors versus later teacher victimization. It can help to increase knowledge about what makes some boys or girls more likely to victimize their teachers and provide helpful results for intervention and prevention strategies.

The results showed that, based on student reports, one in five boys and one in six girls admitted teasing a teacher online. Just under one in 10 boys and girls admitted insulting teachers in the previous six months, and a smaller number reported insulting a teacher online. Boys, overall, reported higher rates of victimization against teachers than girls, which is in line with all the literature on gender differences in bullying, cyberbullying or more generally aggression.

First, we looked at risk factors that could explain boy and girl involvement in teacher victimization at baseline and then we analyzed risk factors that predicted, separately for boys and girls, involvement in teacher victimization after six months. The results showed a similar pattern for boys and girls with regard to their involvement in teacher victimization at baseline. Both low awareness of online risks and low perceived parental support significantly increased students' likelihood of victimizing their teachers. These results are in line with previous studies on teacher victimization and cyberbullying (Baldry, Farrington, \& Blaya, 2018; Jaureguizar et al., 2013; Kapa et al., 2018).

Regarding risk factors that predicted teacher victimization by students after six months, there were some different patterns between boys and girls. Low empathy did not significantly predict teacher victimization for either boys or girls. It might be useful for the future to see whether differences are found if empathy is split into its two dimensions, cognitive and emotional empathy, and whether those (boys or girls) who report low levels of emotional empathy are more likely to victimize teachers, as has been found for cyberbullying (Ang \& Goh, 2010; Topcu \& Erdur-Baker, 2012)

Boys and girls with higher levels of moral disengagement are respectively three times and six times more likely to victimize their teachers in the following six months. This result is of great interest, as moral disengagement is a way for a person committing an immoral action to tend to justify it, either by victim blaming, denial of responsibility, or minimizing the act (Bandura, 1990). Similar to what was found in studies of school bullying and cyberbullying (Bauman, 2010; Menesini, Nocentini, \& Camodeca, 2013; Pornari \& Wood, 2010; Pozzoli, Gini, \& Vieno, 2012), a possible explanation could be that students who victimize their teachers online or offline change their cognitive reasoning and believe that what they do to their teachers is what the teachers deserve.

Students who are less aware of online risks are much more likely to victimize their teachers online and offline, and this pattern is also found in the cyberbullying literature (Baldry et al., 2018), where some actions performed online, even if antisocial in their nature, are minimized and not considered to be damaging (Bauman, 2010). Low parental support was almost significantly predictive for boys, but low peer support 
predicted a reduced risk of teacher victimization for boys. This is interesting, as high peer support could play a role in terms of group pressure and social norms shared among students. Finally, a poor school climate predicted an increased risk of teacher victimization for girls, but not for boys. This result is partially in line with what we were expecting, and it would need further exploration with new research and new data. From these results, it can be concluded that risk factors for teacher victimization are similar to those for peer victimization (Baldry et al., 2015; Kowalski, Giumetti, Schroeder, \& Lattanner, 2014).

These results are of interest because they can help in developing more tailored intervention programs, taking account of gender differences, to reduce teacher victimization by students, including online victimization. Programs could target victimization against teachers and more broadly address the individual skills of students to reduce antisocial behavior and specifically teacher victimization. Based on our results and literature reviews of effective programs to reduce school bullying and cyberbullying (Gaffney, Farrington, Espelange, \& Ttofi, 2018; Gaffney, Ttofi, \& Farrington, 2018), programs that are designed to reduce moral disengagement, increase parental support and improve the school climate, are all possible effective interventions to reduce teacher victimization. Furthermore, our results also underline the importance to develop and implement prevention programs that include activities to increase awareness of online risks, as they had been proven to be effective in reducing youth involvement in cyberbullying and peer aggression (Del Rey, Casas, \& Ortega, 2016; Menesini, Nocentini, \& Palladino, 2012; SchultzeKrumbholz, Schultze, Zagorscak, Wölfer, \& Scheithauer, 2016; Sorrentino et al., 2019; Thompson \& Smith, 2011; Wölfer et al., 2014). Further research should use longer-term longitudinal studies to establish risk factors for onset, persistence, and desistance of teacher victimization, across the years.

The present study has some limitations, mainly related to the sample of students taking part in the longitudinal study, as they might be not representative of the population. Also, the individual and social/interpersonal variables that were used did not cover the full range of all possible individual and interpersonal risk factors. As pointed out by Reddy et al. (2018), better measures of teacher victimization should be developed. In the current study, teacher victimization was measured using only four items and with modest internal consistency. Better measures of online victimization are desirable, addressing the full range of types of victimization of teachers, including video recording and video posting online, spreading rumors on social networks, and the creation of fake teacher profiles on social networks.

By adopting an ecological approach to study risk factors for victimization of teachers, this article has provided a better understanding of the complex relationship of individual and interpersonal risk factors that influence these behaviors. More risk factors, as well as protective factors, should be included in future studies to explain in more detail the complexity of these aggressive behaviors. Several other risk factors, such as family background, violence in the family, and community-level violence could play a role. Nevertheless, this article has advanced knowledge about predictors of teacher victimization based on student reports.

\section{References}

Albiero, P., Matricardi, G., Speltri, D., \& Toso, D. (2009). The assessment of empathy in adolescence: A contribution to the Italian validation of the "Basic Empathy Scale". Journal of Adolescence, 32(2), 393 - 408. doi: 10.101 6/j.adolescence.2008.01.001

Ang, R. P., \& Goh, D. H. (2010). Cyberbullying among adolescents: The role of affective and cognitive empathy, and gender. Child Psychiatry and Human Development, 41(4), 387 - 397. doi: 10.1007/s10 578-010-0176-3

Baldry, A. C., Blaya, C., \& Farrington, D. P. (Eds.). (2018). International perspectives on cyberbullying: prevalence, risk factors and interventions. London, UK: Palgrave Macmillan. 
Baldry, A. C., Farrington, D. P., \& Sorrentino, A. (2015). "Am I at risk of cyberbullying”? A narrative review and conceptual framework for research on risk of cyberbullying and cybervictimization: The risk and needs assessment approach. Aggression and Violent Behavior, 23, 36 - 51. doi: 10.1016/j.avb. 2015.05.014

Baldry, A. C., Farrington, D. P., \& Sorrentino, A. (2017). School bullying and cyberbullying among boys and girls: Roles and overlap. Journal of Aggression, Maltreatment and Trauma, 26(9), 937 - 951. doi:10.1080/109 26771.2017.1330793

Bandura, A. (1990). Selective activation and disengagement of moral control. Journal of Social Issues, 46(1), 27 - 46. doi:10.1111/j.1540-4560.1990.tb00270.x

Bandura, A., Barbaranelli, C., Caprara, G. V., \& Pastorelli, C. (1996). Mechanisms of moral disengagement in the exercise of moral agency. Journal of Personality and Social Psychology, 71(2), 364 - 374. doi: 10.1037/00223514.71.2.364

Bauman, S. (2010). Cyberbullying in a rural intermediate school: An exploratory study. Journal of Early Adolescence, 30(6), 803 - 833. doi: 10.1177/0272431609350927

Benbenishty, R., Astor, R. A., López, V., Bilbao, M., \& Ascorra, P. (2018). Victimization of teachers by students in Israel and in Chile and its relations with teachers' victimization of students. Aggressive Behavior, 45(2), 107 119. doi: 10.1002/ab.21791

Bronfenbrenner, U. (1986). Ecology of the family as a context for human development: Research perspectives. Developmental Psychology, 22(6), 723 - 742. doi: 10.1037/0012-1649.22.6.723

Cappadocia, M. C., Craig, W. M., \& Pepler, D. (2013). Cyberbullying prevalence, stability, and risk factors during adolescence. Canadian Journal of School Psychology, 28(2), 171 - 192. doi:10.1177/ 0829573513491212

Caprara, G. V., Bandura, A., Barbaranelli, C., \& Vicino, S. (1996). La Misura del Disimpegno morale [The assessment of moral disengagement]. Rassegna di Psicología, 13, 93 - 105.

Chen, J. K., \& Astor, R. A. (2009). The perpetration of school violence in Taiwan: An analysis of gender, grade level and school type. School Psychology International, 30, 568 - 584. doi: 10.1177/01430343 09107076

Cross, D., Barnes, A., Papageorgiou, A., Hadwen, K., Hearn, L., \& Lester, L. (2015). A social-ecological framework for understanding and reducing cyberbullying behaviors. Aggression and Violent Behavior, 23, 109 - 117. doi: 10.1016/j.avb.2015.05.016

Curran, F. C., Viano, S. L., \& Fisher, B. W. (2019). Teacher victimization, turnover, and contextual factors promoting resilience. Journal of School Violence, 18(1), 21 - 38. doi: 10.1080/15388220.2017.1368 394

Del Rey, R., Casas, J. A., \& Ortega-Ruiz, R. (2016). The impacts of the CONRED Program on different cyberbullying roles. Aggressive Behavior, 42(2), 123 - 135. doi:10.1002/ab.21608

De Wet, C. (2010). Victims of educator-targeted bullying: A qualitative study. South African Journal of Education, 30, 189 - 201.

Dinkes, R., Cataldi, E. F., \& Lin-Kelly, W. (2007). Indicators of school crime and safety: 2007 (NCES 2008-021/NCJ 219553). Washington, DC: National Center for Education Statistics.

Dworkin, A. G., Haney, C. A., \& Telschow, R. L. (1988). Fear, victimization, and stress among urban public-school teachers. Journal of Organizational Behavior, 9(2), 159 - 171. doi: 10.1002/job.40300 90207

Dzuka, J., \& Dalbert, C. (2007). Student violence against teachers: Teachers' wellbeing and the belief in a just world. European Psychologist, 12, 253 - 260. doi:10.1027/1016-9040.12.4.253

Espelage, D., Anderman, E. M., Brown, V. E., Jones, A., Lane, K. L., McMahon, S. D., .. Reynolds, C. R. (2013). Understanding and preventing violence directed against teachers: Recommendations for a national research, practice, and policy agenda. American Psychologist, 68(2), 75 - 87. doi: 10.1037/a0031307

Espelage, D. L., \& Swearer, S. M. (Eds.). (2004). Bullying in American schools: A socio-ecological perspective on prevention and intervention. Mahwah, NJ: Erlbaum.

Farrington, D. P., \& Baldry, A. (2010). Individual risk factors for school bullying. Journal of Aggression, Conflict and Peace Research, 2(1), 4 - 16. doi:10.5042/jacpr.2010.0001

Gaffney, H., Farrington, D. P., Espelage, D. L., \& Ttofi, M. (2018). Are cyberbullying intervention and prevention programs effective? A systematic and meta-analytical review. Aggressive and Violent Behavior, 45, 134 - 153. doi: 10.1016/j.avb .2018.07.002 
Gaffney, H., Ttofi M., \& Farrington, D. P. (2018). Evaluating the effectiveness of school-bullying prevention programs: An updated meta-analytical review. Aggressive and Violent Behavior, 45, 111 - 133. doi: 10.1016/j.avb.2018.07.001

Gregory, A., Cornell, D., \& Fan, X. (2012). Teacher safety and authoritative school climate in high schools. American Journal of Education, 118, 401 - 425. doi: 10.1086/666362

Hinduja, S., \& Patchin, J. W. (2008). Cyberbullying: An exploratory analysis of factors related to offending and victimization. Deviant Behavior, 29(2), 129 - 156. doi: 10.1080/0163962 0701457816

Hong, J. S., \& Espelage, D. L. (2012). A review of research on bullying and peer victimization in school: An ecological system analysis. Aggression and Violent Behavior, 17(4), 311 - 322. https://doi.org/10. 1016/j.avb. 2012.03.003

Holt, T. J., Fitzgerald, S., Bossler, A. M., Chee, G., \& Ng, E. (2016). Assessing the risk factors of cyber and mobile phone bullying victimization in a nationally representative sample of Singapore youth. International Journal of Offender Therapy and Comparative Criminology, 60(5), 598 - 615. doi: 10.1177/0306624X14554852

Huang, F. L., Eddy, C. L., \& Camp, E. (2017). The role of the perceptions of school climate and teacher victimization by students. Journal of Interpersonal Violence. https://doi.org/10.1177/0886260517721898

Jaureguizar, J., Ibabe, I., \& Straus, M. A. (2013). Violent and prosocial behavior by adolescents toward parents and teachers in a community sample. Psychology in the Schools, 50(5), 451 - 470. doi: 10.1002/pits.21685

Jolliffe, D., \& Farrington, D. P. (2006). Development and validation of the Basic Empathy Scale. Journal of Adolescence, 29(4), 589 - 611. doi: 10.1016/j.adolescence.2005.08.010.7

Kapa, R., \& Gimbert, B. (2018). Job satisfaction, school rule enforcement, and teacher victimization. School Effectiveness and School Improvement, 29, 150 - 168. doi: 10.1080/09243453. 2017.1395747

Kapa, R. R., Luke, J., Moulthrop, D., \& Gimbert, B. (2018). Teacher victimization in authoritative school environments. Journal of School Health, 88(4), 272 - 280. doi: 10.1111/josh.12607

Kauppi, T., \& Porhola, M. (2012). Teachers bullied by students: Forms of bullying and perpetrator characteristics. Violence and Victims, 27, 396 - 413. doi: 10.1891/0886-6708.27.3.396

Khoury-Kassabri, M. (2012). Perpetration of aggressive behaviors against peers and teachers as predicted by student and contextual factors. Aggressive Behavior, 38(4), 253 - 262. doi: 10.1002/ab.21424

Khoury-Kassabri, M., Astor, R. A., \& Benbenishty, R. (2009). Middle Eastern adolescents' perpetration of school violence against peers and teachers: A cross-cultural and ecological analysis. Journal of Interpersonal Violence, 24(1), 159 - 182. doi: 10.1177/0886260508315777

Kowalski, R. M., Giumetti, G. W., Schroeder, A. N., \& Lattanner, M. R. (2014). Bullying in the digital age: A critical review and meta-analysis of cyberbullying research among youth. Psychological Bulletin, 140(4), 1073 - 1137. doi: $10.1037 / \mathrm{a} 0035618$

Longobardi, C., Badenes-Ribera, L., Fabris, M. A., Martinez, A., \& McMahon, S. D. (2018). Prevalence of student violence against teachers: A meta-analysis. Psychology of Violence. doi:10.1037/vio0000202

Martinez, A., McMahon, S. D., Espelage, D., Anderman, E. M., Reddy L. A., \& Sanchez, B. (2016). Teachers' experiences with multiple victimization: identifying demographic, cognitive, and contextual correlates. Journal of School Violence, 15(4), 387 - 405. doi: 10.1080/15388220.2015.10 56879

McMahon, S. D., Martinez, A., Espelage, D., Rose, C., Reddy, L. A., Lane, K., ... Brown, V. (2014). Violence directed against teachers: Results from a national survey. Psychology in the Schools, 51, 753 - 766. doi: 10.1002/pits.217 77

Menesini, E., Nocentini, A., \& Camodeca, M. (2013). Morality, values, traditional bullying, and cyberbullying in adolescence. British Journal of Developmental Psychology, 31(1), 1 - 14. doi: 10.1111/j.2044-835X.2011.0206 6.x

Menesini, E., Nocentini, A., \& Palladino, B. E. (2012). Empowering students against bullying and cyberbullying: Evaluation of an Italian peer-led model. International Journal of Conflict and Violence, 6(2), 313 - 320. doi: 10.4119/UNIBI/ijcv.253

Moon, B., \& McCluskey, J. (2016). School-based victimization of teachers in Korea: focusing on individual and school characteristics. Journal of Interpersonal Violence, 31(7), 1340 - 1361. doi: 10.1177/ 0886260514564156 
Pornari, C. D., \& Wood, J. (2010). Peer and cyber aggression in secondary school students: The role of moral disengagement, hostile attribution bias, and outcome expectancies. Aggressive Behavior, 36(2), 81 - 94. doi: 10.1002/ab.20336

Pozzoli, T., Gini, G., \& Vieno, A. (2012). Individual and class moral disengagement in bullying among elementary school children. Aggressive Behavior, 38(5), 378 - 388. doi: 10.1002/ab.21442.

Reddy, L. A., Espelage, D. L., Anderman, E. M., Kanricha, J. B., \& McMahon, S. D. (2018). Addressing violence against educators through measurement and research. Aggressive and Violent Behavior, 42, 9 - 28. doi: 10.10 16/j.avb.2018.06.006

Runions, K. C., \& Bak, M. (2015). Online moral disengagement, cyberbullying, and cyber-aggression. Cyberpsychology, Behavior, and Social Networking, 18(7), 400 - 405. https://doi.org/10.1089/cyber.2014.0670

Schultze-Krumbholz, A., Schultze, M., Zagorscak, P., Wölfer, R., \& Scheithauer, H. (2016). Feeling cybervictims' pain -The effect of empathy training on cyberbullying. Aggressive Behavior, 42(2), 147 - 156. doi: 10.1002/a b. 21613

Smith, P. K., Mahdavi, J., Carvalho, M., Fisher, S., Russell, S., \& Tippett, N. (2008). Cyberbullying: Its nature and impact in secondary school pupils. Journal of Child Psychology and Psychiatry, 49(4), 376 - 385. doi: 10.111 $1 / \mathrm{j} .1469-7610.2007 .01846 . \mathrm{x}$

SooHyun, O., \& Wilcox, P. (2018). Routine activity theory, target congruence, and school context: a multilevel analysis of teacher victimization. Victims and Offenders, 13(3), 349 - 372. doi: 10.1080/15564886.2017.1329 174

Sorrentino, A., Baldry, A. C., Farrington, D. P., \& Blaya, C. (2019). Epidemiology of cyberbullying across Europe: Differences between countries and genders. Educational Sciences: Theory and Practice, 19(2), 74 - 91. doi: 10.12738/estp.2019.2.005

Steffgen, G., \& Ewen, N. (2007). Teachers as victims of school violence-the influence of strain and school culture. International Journal on Violence and Schools, 3(1), 81 - 93.

Sticca, F., Ruggieri, S., Alsaker, F., \& Perren, S. (2013). Longitudinal risk factors for cyberbullying in adolescence. Journal of Community and Applied Social Psychology, 23(1), 52 - 67. doi: 10.100 2/casp.2136

Thompson, F., \& Smith, P. K. (2011). The use and effectiveness of anti-bullying strategies in schools. Research Report, DFE-RR098. London: Department for Education.

Topcu, Ç., \& Erdur-Baker, Ö. (2012). Affective and cognitive empathy as mediators of gender differences in cyber and traditional bullying. School Psychology International, 33(5), 550 - 561. doi: 10.1177/0 143034312446882

Vanden Abeele, M. M., Van Cleemput, K., \& Vandebosch, H. (2017). Peer influence as a predictor of producing and distributing hurtful images of peers and teachers among Flemish adolescents. Journal of Children and Media, 11(1), 69 - 87. doi: 10.1080/17482798.2016.1233123

Wilson, C. M., Douglas, K. S., \& Lyon, D. R. (2011). Violence against teachers: Prevalence and consequences. Journal of Interpersonal Violence, 26, 2353 - 2371. doi: 10.1177/088626051038 3027

Yang, C., Jenkins, L., Fredrick, S. S., Chen, C., Xie, J. S., \& Nickerson, A. B. (2019). Teacher victimization by students in China: A multilevel analysis. Aggressive Behavior, 45(2), 169 - 180. doi: 10.1002/ab.2 1806

Wölfer, R., Schultze-Krumbholz, A., Zagorscak, P., Jäkel, A., Göbel, K., \& Scheithauer, H. (2014). Prevention 2.0: Targeting cyberbullying@ school. Prevention Science, 15(6), 879 - 887. doi: 10.100 7/s11121-013-0438-y

Zimet, G. D., Dahlem, N. W., Zimet, S. G., \& Farley, G. K. (1988). The Multidimensional Scale of Perceived Social Support. Journal of Personality Assessment, 52, 30 - 41. doi: 10.1207/s15327752jpa5201_2.0.1080/1538 8220.2013 .857346

Zimet, G. D., Powell, S. S., Farley, G. K., Werkman, S., \& Berkoff, K. A. (1990). Psychometric characteristics of the multidimensional scale of perceived social support. Journal of Personality Assessment, 55(3-4), 610 - 617. doi: 10.1080/00223891.1990.9674095

Zych, I., Baldry, A. C., Farrington, D. P., \& Llorent, V. J. (2019). Are children involved in cyberbullying low on empathy? A systematic review and meta-analysis of research on empathy versus different cyberbullying roles. Aggression and Violent Behavior, 45, 83 - 97. doi: 10.1016/j.avb.2018.03.004 